\title{
Making the Case for a Linguistic Investigation of Greek Lexicography: Some Examples from the Byzantine Reception of Atticist Lemmas
}

\begin{abstract}
Ancient lexica give us important information about linguistic evolution and its perception by native speakers. However, linguistic investigations of lexicographical material are slow to come to the forefront of Classical linguistics and even more so of Medieval Greek linguistics. This paper makes a contribution in this direction by investigating the relevance of lemmas handed down from Atticist lexicography in the linguistic context of Medieval Byzantium, where writers had to move between different registers and were often confronted with the differing usages of the two most important models: the Classics and the Scripture.
\end{abstract}

Keywords: Atticism, lexicography, post-Classical Greek, Byzantine Greek, Medieval Greek.

\section{Approaching Ancient Lexicography from a Linguistic Perspective}

The paths through which knowledge of Ancient Greek has unfolded across time are very often traced in the pages of dictionaries. Ancient and medieval Greece are no exception. Ever since the Hellenistic Age, Greek erudition has devoted great attention to collecting rare words ( $\gamma \lambda \tilde{\omega} \sigma \sigma \alpha \mathrm{s})$ or notable terms $(\lambda \dot{\varepsilon} \xi \varepsilon \iota \varsigma)$ and glossaries and lexica have had an important role in Greek learning and, consequently, in perpetuating the multifarious character of the language. The usefulness of ancient lexica for modern readers obviously does not reside uniquely in the old, rare or important words which they collect. Yet modern readers often tend to treat these sources as mere ancillary tools and not as scholarly works in their own right, with the result that there is little interest in the reasons why certain lemmas were included in a lexicon, or in the methodology and linguistic reasoning behind certain interpretamenta.

Similarly, scholars of Antiquity rarely address the semiotic and hermeneutical questions elicited by the very ontology of the container, the lexicographical 'list' itself. Some of these questions can be illustrated with examples from the 
great tradition of Atticist lexicography. The first obvious fact is that the 'list' may often be only the result of the compression of a different kind of work: a case in point is the epitome of Phrynichus' Praeparatio sophistica, originally a huge discursive treatise on rhetorical style in 37 books, now consisting of fragments and scattered citations in other works. Unlike modern dictionaries, these 'lists' were always an open product, in which information was edited in and out according to the interests and dispositions of their compilers and conveyors: this is particularly obvious in the case of onomasiological dictionaries such as Pollux's Onomasticon, in which new terms were added to the original collection by later compilers. When we are faced with works which, like the Praeparatio sophistica and Pollux's Onomasticon, are characterized by a spare style and reduced syntax, another question that arises is whether these were original features or the result of later shortening and, following from this, whether it is possible to identify the authorial 'voice' and methodology of such works.

In the last twenty years or so some of these issues and others have begun to find a place in Classical scholarship, which is slowly integrating the traditional textual-philological approach (according to which lexica are the object of Textkritik, Textgeschichte or Überlieferungsgeschichte) with a more fine-grained investigation of the methodology and theoretical stances underlying the ancient lexica. In the realm of Atticist lexicography, for instance, Stefanos Matthaios has made a good case for the identification of a theory of linguistic registers and sociolects in the hitherto seemingly undifferentiated terminology of Pollux's Onomasticon. ${ }^{1}$ Before him, the need to take Atticist lexica seriously and to analyze them with a linguistically oriented approach was defended by Albio Cassio in a brief but paradigmatic contribution on the role of the Antiatticist as an advocate of those koine and dialectal forms which were condemned by Atticism. ${ }^{2}$ Cassio's interest in revealing the Atticist lexicographers' nuanced views on language has inspired fruitful lines of research on the part of his older and younger pupils: a case in point is Carlo Vessella's work on correct pronunciation in Atticist lexicography, a topic that according to past scholarship the Atticists were hardly interested in. ${ }^{3}$

1 Matthaios 2013; Matthaios 2015.

2 Cassio 2012.

3 Vessella 2010; Vessella 2018. At the University of Cambridge Chiara Monaco is at work on a $\mathrm{PhD}$ thesis on the Atticist take on comic language, which issues from the MA she completed at Rome under Cassio's supervision (Monaco 2015). For further work on the linguistic theorization of Atticist lexicography see Tribulato 2014; Tribulato 2016; Tribulato 2018. 
While we are now beginning to be better equipped to undertake a linguistic study of the Atticist take on issues of language correctness and linguistic evolution, the survival of Atticist material in the Byzantine Age, and particularly in its lexica, still awaits - with very few recent exceptions - to be addressed in a truly linguistic perspective. ${ }^{4}$ This contribution seeks to make a small step in this direction by investigating what linguistic motivations may lurk behind the Byzantine interest in certain ancient glosses. The inspiration behind this pilot study comes from a recurrent piece of advice that Albio Cassio, following in the footsteps of eminent Greek linguists such as Albert Thumb, always gave his pupils: that we should not be blind to the post-Classical (i.e. Byzantine and modern) evolution of Greek if we wish to understand the ancient roots of the language. ${ }^{5}$

\section{Lexicography at Byzantium: From Textgeschichte to Linguistics}

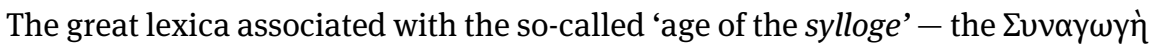

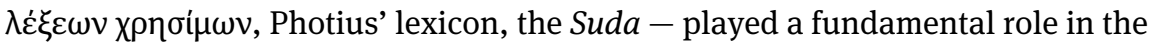
survival of ancient exegetical material and its transmission to later ages, by collecting and systematizing a lexicographical heritage that would have otherwise been lost. ${ }^{6}$ The intellectual circles of 9th-century Constantinople were also responsible for the epitomizing and copying of Atticist works such as Pollux's Onomasticon as well as those which were collected in the slightly later lexicographical miscellany of cod. Paris. Coislinianus gr. 345. This important collection of ancient lexicography, to which we will be returning at several stages in this paper, contains the only extant copy of the Antiatticist, the epitome of Phrynichus' Praeparatio sophistica, an important 'expansion' of the Synagoge $\left(=\Sigma^{\mathrm{b}}\right.$ once known under the name of 'Lexicon Bekkeri VI': see Section 3), and Moeris' Atticist, as well as other important lexica. ${ }^{7}$

4 For partial exceptions see Matthaios 2006 and Matthaios 2010, both on the Suda, and Cuomo 2017, on lexica, school manuals and their usefulness for a socio-linguistic investigation of Medieval Greek.

5 This is theorized in Cassio 2014.

6 On the pivotal exegetical activity of this period see Lemerle 1971; Hunger 1978, 33-50; Pontani 2015.

7 The early history of cod. Paris. Coisl. gr. 345 is reconstructed in de Leeuw 2000; Cunningham 2003, 57; Valente 2008; Valente 2012, 28-30; Valente 2015, 12. The idea that Arethas of Caesarea is directly behind the manuscript has now been abandoned, but some parts of the codex may 
While eminent philologists have produced seminal studies on the Textgeschichte and Überlieferungsgeschichte of Byzantine lexica, ${ }^{8}$ a substantial gap still extant in modern literature concerns the way in which lexicography interacted with and impacted language development during the Byzantine Age. The limited interest in the socio-linguistic dimension of these works is a result of the combined effect of two attitudes. First, the widespread prejudice that Byzantine lexica, like most works of this age, are repetitive and unoriginal, nothing more than expanded mechanical compilations. ${ }^{9}$ Secondly, the general neglect of linguistics in the tradition of Byzantine studies. ${ }^{10}$ Among other evident shortcomings, this has produced a bizarre situation in which linguists may be interested in ancient lexicography, but not at all in its Byzantine counterparts, in spite of the fundamental role played by the latter from the point of view of language transmission. This neglect supports the statement that "the history of manuscripts passes through Byzantium [...] the history of ideas and literature routinely jumps from St. Augustine to the Renaissance” (Kaldellis 2007, 4).

One may well be inclined to ask: why would such specialist works have had a role in the evolution of Medieval Greek? For Greek speakers in Byzantium, lexica of course were first and foremost a guide to the Classical language and its creative reproduction in Byzantine literature. ${ }^{11}$ But lexica in fact also contain valuable indirect information about the Byzantines' view of their own language and can be argued to rank among those texts which were "factors of linguistic variation and change and influenced the choices of medieval authors" (Cuomo 2017, 452). This kind of information is all the more valuable because the Byzantine grammatical tradition, albeit rich, is remarkably silent on the topic of the language of its day. ${ }^{12}$ In past scholarship the appreciation of the Byzantine relation with ancient culture and language has suffered from the idea that it was merely an exercise in slavish imitation steeped in a static diglossia which opposed learned and archaizing 'Byzantine Greek' to the spoken, low-level 'vernacular' or

reflect the activity of his circle, as cautiously proposed by Ucciardello 2006, 63 n. 119 and Ucciardello 2012b, 91-94. Arethas also had a role in the transmission of Pollux's Onomasticon: see Bethe 1900, v-vi.

8 Seminal studies concerning the Textgeschichte are e.g. Reitzenstein 1897; Erbse 1950; Trapp et al. 1988; Hörandner/Trapp 1991; Trapp/Schönauer 2007. Classic and more recent general introductions are Cohn 1900; Tolkiehn 1925; Alpers 1990; Alpers 2001; Tosi 2015.

9 Thus Alpers 2001, 205: "nichts weiter als weitgehend mechanische Kompilationen aus den ihnen vorliegenden Quellen".

10 See Manolessou 2014, 13.

11 See e.g. Hunger 1991 on the Suda.

12 Robins 1993; Manolessou 2014. 
'Medieval Greek'. ${ }^{13}$ Recent scholarship, however, has replaced this somewhat stereotyped view with a more fine-grained approach, claiming that the linguistic situation of medieval Byzantium was characterized by a linguistic continuum in which choices of style, register, vocabulary and grammar could vary considerably not only from the written to the spoken level (as scholarship has always assumed) but even within the writings of the same author(s). ${ }^{14}$

These new lines of research have not yet made an impact on theoretical approaches to Byzantine lexicography. We continue to assume that Byzantine lexicographers registered certain ancient words because (a) they were used in the great literary works of the Classical past and/or (b) because they were rare terms, and hence difficult for Byzantine readers. While it is certainly true that both criteria must have informed a lot of the choices made in Byzantine lexica, such a backward-looking viewpoint - which keeps explaining Byzantium by turning to the Classical past - risks levelling out the constituent criteria of Byzantine lexicography to a mere erudite game, thus overshadowing the motivations behind the perpetuation of lemmas which do not completely fall under criteria (a) and (b) above. Why were Byzantine lexicographers interested in words coming from works which were no longer read in their times (e.g. Doric comedy)? Conversely, why were lemmas used by famous Classical authors and included in ancient lexicography dropped in Byzantine lexica? A case in point is Phrynichus Eclogae 54 Fischer. This entry recommends using the verb $\kappa \alpha \tau \alpha \delta \alpha \iota \mu$ oเvó $\omega$ in its correct Attic

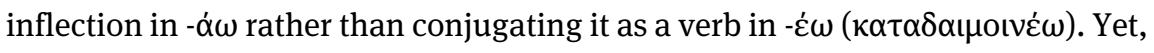
with the unique but understandable exception of the late-medieval lexicon of Thomas Magister (who heavily draws on Phrynichus), Byzantine lexica are silent on both forms. In spite of Phrynichus' recommendation and of the Attic pedigree of $\kappa \alpha \tau \alpha \delta \alpha \iota \mu$ ovó $\omega$, this form simply dropped out of use: but why, since it was an erudite relic, were lexicographers not interested in it? ${ }^{15}$

The answer to this and similar questions would of course require a wide-ranging study of the main Byzantine lexica in relation to their ancient antecedents as well as of the different transmission paths and the Nachleben of the literary works

13 E.g. Meillet 1930, 23; Böhlig 1956; Beck 1971, 1-4; Hunger 1969-1970, 29-30. For the terminological divide, see Rollo 2008.

14 For examples of this approach see e.g. Ševčenko 1981; Trapp 1993; Toufexis 2008; Hinterberger 2014; Horrocks 2014.

15 As far as one can ascertain, in post-Classical Greek the verb is almost always inflected in the

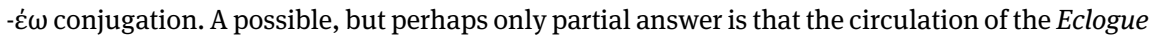
was limited before the age of Thomas Magister: I thank Giuseppe Ucciardello for pointing this out to me. Still, this does not explain why Phrynichus' lemma was not picked up by later ancient lexica. 
of Antiquity, an enterprise which is well beyond the scope of an article. Here I will tackle a few concrete examples originating in Atticist lexicography in order to highlight some linguistic facts which may have guided the Byzantine re-use of certain ancient lemmas. I will start with the two 'traditional' criteria ruling the selection of the lemmas mentioned above, namely: (a) the fact that a certain word was used in the great works of the Classical past which were considered models (Section 3) and (b) the fact that a certain ancient word may have been difficult for Byzantine readers because it had dropped out of use (Section 4). In the last part of the paper (Section 5) I will turn to investigate a third criterion, i.e. the fact that a certain word may be registered by Byzantine lexica because its semantics had undergone a complex evolution in the transition from Ancient to Byzantine Greek and hence required special attention. It may be argued that this third criterion is a subcategory of one or both of the other two. Indeed, educated medieval Greeks may be interested in certain words which they still used precisely because they were also used by the ancients (criterion a) or, in the case of semantic change, because the modern meaning had no parallels in Ancient Greek (criterion b). However, by introducing a third criterion I will make the case for the importance of a diachronic linguistic approach to Byzantine lexicographical material: this approach, I wish to argue, will help us understand the relevance that certain words may have had for Byzantine scholars who lived in a diglossic situation.

\section{Bolstering Attic: A Diagnostic Example}

A good example of the way Byzantine lexicography perpetuated the linguistic us-

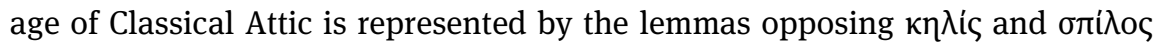
(both 'stain, blemish'). ${ }^{16}$ In his lexicon Photius devotes two entries to кn $\lambda$ is:

16 Properispomenon accentuation in Fischer (1974) likely depends on some uncertain information that Lentz collected and edited as Hdn. GG 3.1, 154.17-22, where $\sigma \pi \tilde{\imath} \lambda$ oৎ is added from

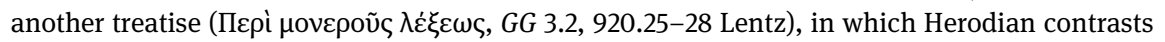
words with $\varepsilon$ l with those in $\mathrm{l}$. Most modern editions and dictionaries disregard Herodian's testi-

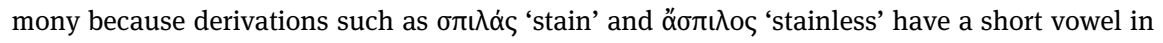
metrical texts, though evidence for the short quantity of these derivations is late. On the problem of vowel quantity and diachrona in Atticist thought, see Vessella 2018, 64-95; his treatment of iota (Vessella 2018, 92) does not mention oti่ orthoepic prescription in the Atticist lexica. 
Making the Case for a Linguistic Investigation of Greek Lexicography: Some Examples from the Byzantine Reception of Atticist Lemmas

(1) $\kappa \eta \lambda \tilde{\delta} \delta \varepsilon \varsigma \cdot \sigma \pi i \lambda o t$.

(Phot. $\kappa 660$ Theodoridis)

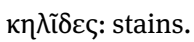

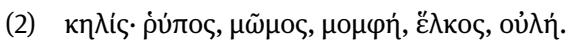

(Phot. $\kappa 662$ Theodoridis)

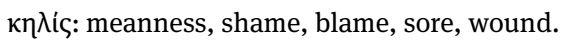

The two lemmas seem to account for different semantic functions of kn $\lambda$ ic. The entry under (1) refers to the concrete meaning of the word ('stain'), which is likely to have been its original meaning. It is no accident that the lemma refers to $\kappa \eta \lambda \tilde{\imath} \delta \varepsilon \varsigma$ in the plural, since the first attestations of the plural in Attic tragedy are not metaphorical. (1) may therefore have a specific Atticist background (see no. (3) below). ${ }^{17}$ From its original meaning of a fleck of blood, by metaphorical extension $k \eta \lambda$ is came to indicate its cause (a wound) and ethical counterpart (a moral or spiritual blemish). ${ }^{18}$ The lemma under (2) accounts for these metaphorical us-

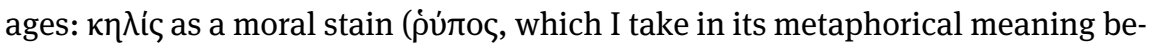

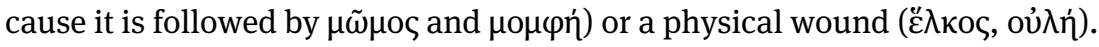

As far as we can see, $\kappa \eta \lambda$ i $\zeta$ was frequently used by Attic authors and later spread to various registers of Greek. It is clear that by the 2nd century AD it had become the more common synonym of ori $\lambda$ os, as Phrynichus implies by condemning the latter:

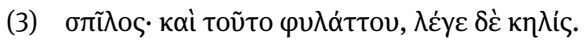

(Phryn. Eclogae 20 Fischer)

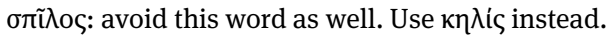

Although throughout its history $\sigma \pi i \lambda$ i Greek it was associated with the lower registers of the koine. Since it featured in two influential passages of the New Testament - St. Paul's Epistle to the Ephe-

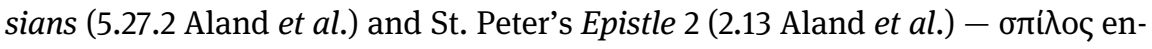

17 The two entries in Photius' have close parallels in Hesychius' lexicon ( $\kappa 2504$ Latte and $\sigma 1514$ Hansen). Both lexica may ultimately draw on Diogenianus, as Theodoridis (ad Phot. $\kappa$ 660) tentatively suggests.

18 The etymology of кn $\lambda$ iç is a matter of debate, but GEW links it to other IE terms indicating a kind of pallor (Lat. cāllidus, Umbr. kaleřuf, Lith. kalýbas), a stain (Skt. kalmașa, a loanword, OI caile), or a dark colour (Skt. kāla-). 
joyed huge popularity in Christian Greek and religious exegesis. Phrynichus' rejection of the word, paired with his endorsement of $\kappa \eta \lambda$ is - the supremacy of which is based on its being an Attic term - is very likely the reason behind Pho-

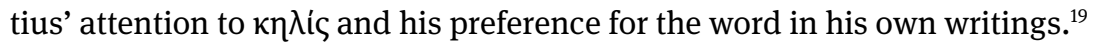

Attic prestige also explains a second example, which Byzantine lexicography inherits from Phrynichus' Eclogue:

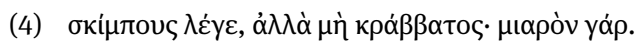

(Phryn. Eclogae 41 Fischer)

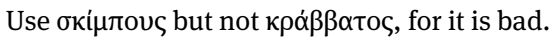

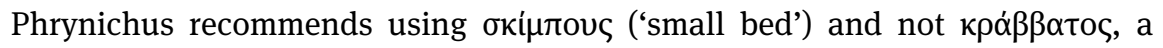
koine word of non-Greek origin which is continued in the Modern Greek form $\kappa \rho \varepsilon \beta \alpha \dot{\tau t .}{ }^{20}$ As far as one can ascertain, both words could be used alternatively to name a small single bed of lowish quality, perhaps nothing more than a wooden

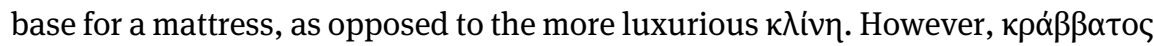
seems to have been associated with Hellenistic Greek and this is probably the reason why Phrynichus condemns it: it was standard word for 'bed' in the New Testament, and even Pollux cannot find any better authorities than the Hellenistic and non-Attic playwrights Rhinton (fr. 9 K.-A.) and Crito (fr. 2 K.-A.) to defend it. бкíлочৎ, on the contrary, could be said to have a Classical Attic pedigree: it is used by Aristophanes (Nub. 254; 708), Plato (Prt. 310d.1) and Xenophon (An.

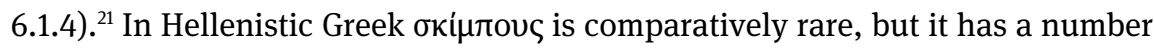
of attestations in 'good' authors variously linked to Atticism such as Lucian, Aelius Aristides and Dio Cassius; Pollux quotes it three times as a synonym of 'bed'.22

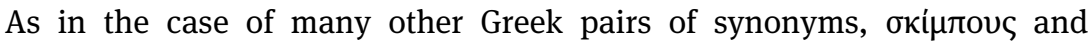

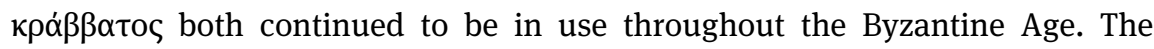

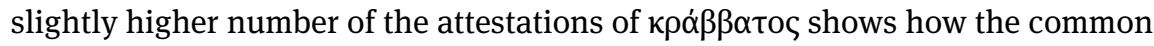

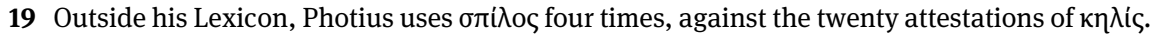
20 The etymology is uncertain. GEW s.v. endorses Paul Kretschmer's view that it was a Macedonian-Illyrian word, while $E D G$ s.v. connects it to $\sigma \kappa i \mu \pi \tau о \mu \alpha$.

21 In the Clouds this is the bed or small couch on which Socrates makes Strepsiades sit during his 'initiation' into the school (Nub. 254) and on which Strepsiades is reclining during his fight with bedbugs: the contrast may therefore be between the eccentric ritual of initiation into the exclusive Socratic school and the prosaic reality of its context (see Dover 1968, 131). The attestations in Plato and Xenophon further clarify that this was a lower-quality bed, which could be easily transported and also used as a field-bed (see Pritchett 1956, 231) or a hammock. On the бкí $\mu$ тоu in general, see Rodenwaldt 1927.

22 Poll. 6.9; 10.35; 10.36 Bethe. 
word managed to enter literary language in spite of competition from the higherregister synonym. This is well illustrated by Thomas Magister ( $\sigma 333$ Ritschl) who, drawing on Phrynichus and perhaps also on the terminology of some other

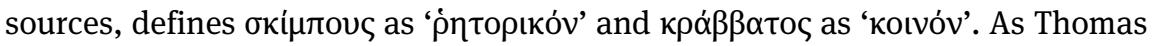
Magister's comments show, the attention devoted to бкí and Byzantine lexicographers was no doubt meant to perpetuate the use of an ancient word associated with the Attic dialect against the much more common

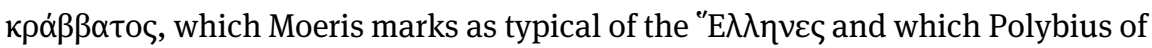
Sardi condemned as a barbarism. ${ }^{23}$ Earlier Byzantine sources provide a clear

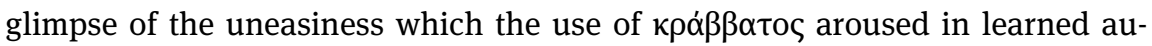
thors:

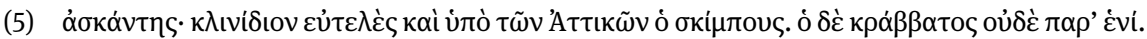
$\left(\Sigma^{\mathrm{b}} \text { a } 2238 \text { Cunningham }\right)^{24}$

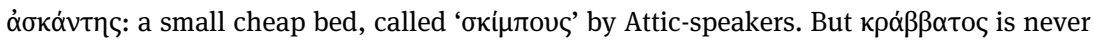
attested in any of them.

This lemma belongs to the 'expanded version' of the $\Sigma v v \alpha y \omega y \grave{\eta} \lambda \varepsilon \dot{\xi} \xi \omega \nu \chi \rho \eta \sigma i \mu \omega v$, the important anonymous lexicon assembled in the late 8th century which has survived through a copy close to the original preserved in two manuscripts (Paris. Coisl. gr. 347 and Paris. Suppl. gr. 1243 I). The expanded version of the Synagoge, to which I here refer with the conventional abbreviation ' $\Sigma^{\mathrm{b}}$, ${ }^{25}$ is instead preserved in cod. Paris. Coisl. gr. 345 as well as in quotations in Photius and the Suda depending on other similar expanded versions. ${ }^{26}$ While $\Sigma$ (the original version of

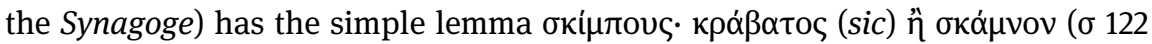
Cunningham) and no entry for áokóvins, the entry in $\Sigma^{\mathrm{b}}$ (no. (5) above) clearly

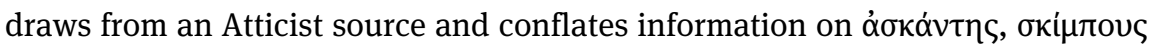

23 Cf. Moer. $\alpha 119$ and $\sigma 33$ Hansen; Polybius Rhetor 285.7-9 Nauck.

24 Cf. Phot. $\alpha 2958$ Theodoridis; Eust. Od. 2.302.44-45 Stallbaum.

25 The expanded version of the Synagoge contained in cod. Paris. Coisl. gr. 345 ("versio codicis $B$ " in Cunningham 2003) mostly contains additions to the letter $\alpha$. These depend on lost expanded versions of the original Synagoge which were independently used also by Photius, the Suda, and the Etymologicum Genuinum. To account for the different origins of these additions in $\alpha$ Cunningham 2003, 49-50 distinguishes glosses in cod. B with three sigla: $\Sigma^{\prime}$ (a version of $\Sigma$ used by B, Photius and the Suda), $\Sigma^{\prime \prime \prime}$ (a version of $\Sigma$ used by B and Photius only), $\Sigma^{\mathrm{b}}$ ("glosses found only in B [...] or occasionally only in B and Et. Gen.”). For our present purposes it is not important to distinguish between these different expanded versions: I have therefore used the generic siglum $\Sigma^{\mathrm{b}}$ to refer to all glosses transmitted in the expanded version(s) of B.

26 The transmission history of this important lexicon has been magisterially reconstructed and explained by Reitzenstein 1907 and Cunningham 2003, 13-14; 43-58. 


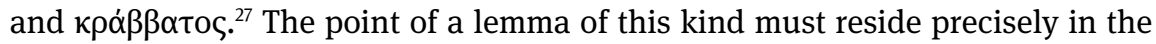

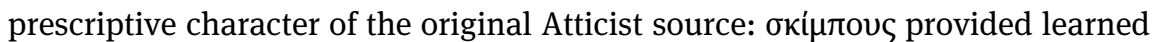

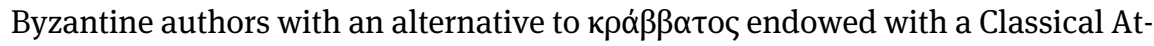
tic ancestry.

\section{Ionic, Attic and What Was Interesting for Byzantine Scholars: A Case-study from Herodotus}

Although profoundly influenced by Atticism, high-register Byzantine Greek did not look to Attic as the only ancient variety worthy of imitation. The Byzantines' creative dialogue with ancient models suggests a form of classicism in which nonAttic models could also find a place. Two cases in point are Homer and Herodotus, whose authority Atticism itself never challenged and who remained reference points for poetic and prose style throughout the Byzantine Age. ${ }^{28}$ With these authors, the linguistic negotiation carried out by Byzantine writers is more subtle, because of course the Homeric Kunstsprache and Herodotus' Ionic are phonologically and morphologically far from Classical Attic: the available evidence suggests the re-working of phrases, lines and words, as well as the more common practice of quoting verbatim certain passages, rather than a direct imitation of linguistic traits. ${ }^{29}$

Addressing the standing enjoyed by Herodotus in Byzantium, however, is no easy task, since there is no general study of his Byzantine reception. The narrower

27 This source may be Moer. 119 Hansen, unless the gloss came to the Synagoge via Hesychius (and Diogenianus). Cunningham 2003, 50-57 addresses the expansions of the Synagoge and their addition of Atticist material to the original version (which mostly follows the neutral orientation of its main source, Cyril's lexicon), while Cunningham 2003, 43-48 discusses the relationship between Cyril and $\Sigma$. The 'neutral' glossing of the word also characterizes three entries in Hesychius ( $\sigma$ 994, 996, 997 Hansen) which are sometimes repeated in later lexica.

28 On this role of Herodotus in the age of linguistic Atticism see Tribulato 2016.

29 Homer remained a staple of Greek education and rhetorical training throughout the Byzantine Age: see e.g. Browning 1992. Herodotus, on the other hand, remained a model of 'pleasurable' prose and narrative style (e.g. Psellus, Orationes panegyricae 1.155 and 8.41 Dennis): the cultural reasons for his enduring popularity in Byzantine times are discussed by Kaldellis 2012, 79, who also briefly addresses Thucydides' different standing in Byzantine rhetoric. 
question of how Herodotean language was viewed by Byzantine writers and represented in contemporary lexicography has been completely ignored.$^{30}$ A quick check on the Index of Cunningham's edition of the Synagoge shows that a considerable part of the Herodotean material contained in this lexicon may have come from Atticist sources (either directly or via intermediaries). ${ }^{31}$ It is therefore to be expected that the Synagoge inherited the contrastive structure of Atticist lexicography, opposing Attic and non-Attic phonological and morphological features and semantics. A good illustration of this is the lemma of $\Sigma^{\mathrm{b}}$ commenting on the inflection of the infinitive of $\alpha \dot{\pi} \pi$ х $\rho \dot{\alpha} \omega$ :

(6)

( $\Sigma^{\mathrm{b}} \alpha 2035$ Cunningham)

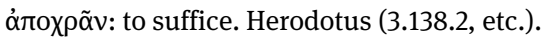

The point of this entry (which finds numerous closer or looser parallels in other Byzantine lexica and etymologica) most probably is not, as it may appear at first

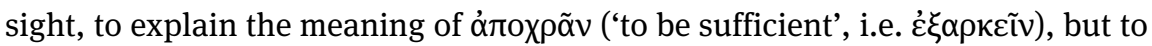
alert readers to the fact that while in Attic $\chi \rho \alpha \dot{\omega} \omega$ and its compounds contract in

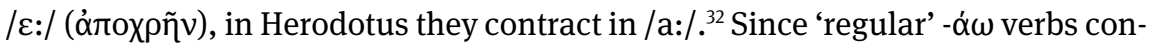
tract /ae/ into /a:/, not / $\varepsilon: /$, the layman (just like the modern student) must have

30 It is remarkable that none of the major companions to Herodotus (e.g. Bakker/de Jong/van Wees 2002; Dewald/Marincola 2006) has a chapter on the Greek Middle Ages. This is all the more striking in the case of Priestley/Zali 2016, given its overt focus on reception (the key-word 'Byzantium' is even missing from the Index). The papers given at the conference The Afterlife of Herodotus and Thucydides at the Warburg Institute in March 2014, including Elizabeth Jeffreys' "Byzantine Receptions of Herodotus and Thucydides", do not appear to have been published yet.

31 According to Cunningham's index, there are nineteen lemmas in the Synagoge that mention Herodotus by name, most of them in $\Sigma^{\mathrm{b}}$. Of these nineteen lemmas, three have been attributed to fragments of Phrynichus' Praeparatio sophistica by its editor, de Borries: $\Sigma^{\mathrm{b}} \alpha$ 472, 806, 2201 Cunningham (the latter with loose parallels in Antiatt. a 138 Valente and Phryn. Eclogae 66 Fischer, both without attribution to Herodotus); two may come from Aelius Dionysius ( $\alpha$ 522, 2156 Erbse) and two ( $\alpha$ 711, 2035 Erbse) from the Antiatticist. As for $\Sigma$, at least $\sigma 108$ comes from Aelius Dionysius.

32 Orus fr. 13 Alpers (= Pseudo-Zonar. 274 Tittmann), on which see no. (9) below; Suda $\alpha 3652$ Adler; schol. Lucian 214.26 Rabe and, with a different verbal form, Phot. $\alpha 2724$ Theodoridis (on which see below). 


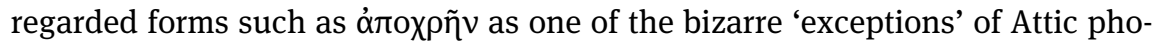
nology (which is indeed how they are regarded today). ${ }^{33}$ Yet, in spite of its irregularity, it was the Attic contraction that learned Greek writers adopted in their

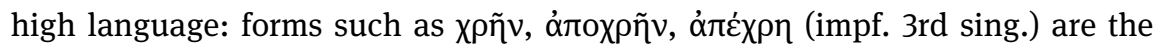
norm in literary texts. This is but another example of the overpowering prestige of Attic, which won against morphological regularity and the pressure of analogy.

In post-Classical spoken Greek, however, the situation may have been quite different. Papyri and inscriptions alike bear traces of analogical forms such as

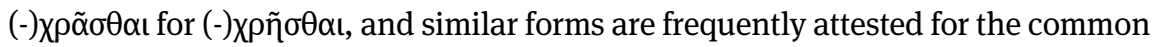
verbs $\pi \varepsilon i v \alpha \dot{\alpha} \omega$ and $\delta \iota \psi \alpha \dot{\alpha} \omega$, which in Attic contracted in $/ \varepsilon: / .^{34}$ This points to the fact that the all too natural 'return' to the regular - $\alpha \omega$ inflection of verbs such as $\chi \rho \alpha \dot{\alpha} \omega$, $\pi \varepsilon เ v \alpha \dot{\alpha} \omega$ and $\delta ı \alpha \dot{\alpha} \omega$ must have been a widespread phenomenon in Hellenistic and Medieval Greek alike. One piece of evidence is the way these verbs are conjugated in Modern Greek and its dialectal varieties, where $\pi \varepsilon เ v \alpha \dot{\alpha} \omega / \pi \varepsilon ı v \omega \dot{~} \delta \iota \psi \alpha \dot{\alpha} \omega / \delta \iota \psi \omega \dot{\omega}$ follow the same conjugation as $\left.\tau \mu \alpha \dot{\alpha} \omega / \tau \iota \mu \dot{~(w i t h ~ e . g . ~ 3 r d ~ p e r s . ~ s i n g . ~} \pi \varepsilon เ v \alpha \dot{\alpha} \varepsilon / \pi \varepsilon v \alpha^{2}\right)^{35}$

Clearly, the correct preservation of the Attic inflection of $\chi \rho \alpha \dot{\omega} \omega$ was already a preoccupation for Atticist lexicographers, as the following entries show:

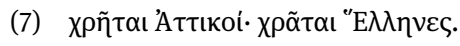

(Moer. $\chi 5$ Hansen)

$\chi \rho \tilde{\tau} \tau \alpha$ in Attic; $\chi \rho \tilde{\tau} \tau \alpha \iota$ in koine Greek.

33 The same phenomenon concerns verbs such as $\pi \varepsilon เ v \alpha \dot{\omega} \omega$ and $\delta \iota \psi \dot{\alpha} \omega$, on which see the still very good overview by Kühner/Blass 1892, 139. The motivations behind the Attic inflection are debated: $E D G$ s.v. $\delta ı \psi \alpha \dot{\alpha} \omega$ and $\pi \varepsilon เ v \alpha \dot{\alpha} \omega$ does not endorse the view (based on Homeric forms such as $\delta เ \psi \alpha \dot{\alpha} \omega \nu, \pi \varepsilon เ v \alpha \dot{\alpha} \omega \nu$, with /a:/) that these verbs had a stem in /a:/. As concerns $\chi \rho \alpha \dot{o} \mu \alpha \mathrm{\alpha}$, it would be

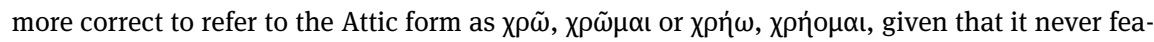
tures an /a/ (cf. Moulton 1908, 54).

34 See Reinhold 1898, 84, who focuses on the Apostolic Fathers and apocryphal gospels; Schweizer 1898, 175 on the Hellenistic inscriptions of Ephesus; Moulton 1908, 54 on the New

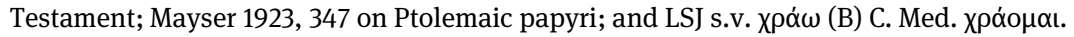

35 A note on $\zeta \tilde{\eta} v$ is necessary here. Although ancient and modern grammars alike tend to treat

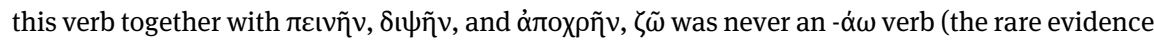
for an inflection in /a/ in late Byzantine lexicographical sources is due to fallacious analogical reasoning). In non-Attic Greek the verb is $\zeta \dot{\omega} \omega$ : both $\zeta \dot{\omega} \omega$ and $\zeta \tilde{\omega}$ are innovations, given that the IE root is reconstructed as ${ }^{\star} g^{w} i h_{3^{-}}$. In Modern Greek the verb $\zeta \omega$ has fallen together with verbs

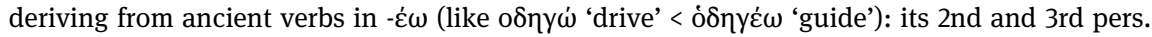
sing. are $\zeta \varepsilon ı$, , $\zeta \varepsilon$. These forms must continue the Attic forms $\zeta \tilde{n} \varsigma, \zeta \tilde{n}$, which in later Greek were pronounced itacistically, and not the by-forms $\zeta \dot{\omega} \omega, \zeta \dot{\omega} \varepsilon ı, \zeta \zeta \dot{\omega} \varepsilon$ etc. of other varieties of Greek. The ancient spelling $\zeta \tilde{n} \varsigma, \zeta \tilde{n}$ apparently was preserved in some 19th-century Modern Greek dialectal varieties: see Hatzidakis 1892, 128. 
Making the Case for a Linguistic Investigation of Greek Lexicography: Some Examples from the Byzantine Reception of Atticist Lemmas

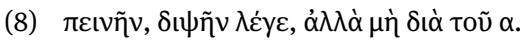

(Phryn. Eclogae 39 Fischer)

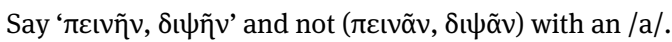

(7) provides clear proof that the Atticists were at pains to reinforce the correct Attic vocalism against the development of koine Greek, while (8) testifies that the analogical treatment also affected $\pi \varepsilon \iota v \alpha \dot{\alpha} \omega$ and $\delta \iota \psi \alpha \dot{\alpha} \omega$. Since, on the whole, Byzantine writers continued to comply with the Atticist model, the Synagoge lemma under (6) may simply have been meant to preserve an erudite piece of information concerning the dialectal variety of a Classical author, Herodotus.

It is intriguing, however, to think that the point of this lemma was precisely to trace back the roots of a feature of spoken Medieval Greek (infinitives in - $\tilde{\alpha} v$ and not in - $\tilde{\eta} v$ ) to the Classical Age. This intention may have been present already in pre-Byzantine lexica. A puzzling entry is found in Orus' lexicon, or rather in what has survived in Pseudo-Zonaras:

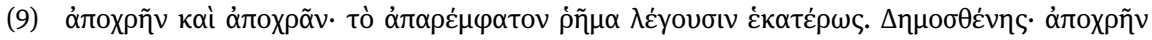

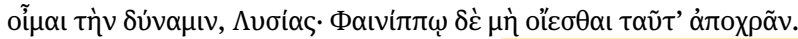

(Orus fr. 13 Alpers = Pseudo-Zonar. 274 Tittmann)

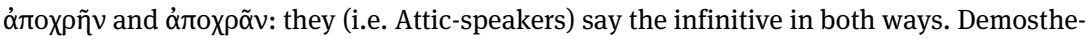
nes (4.22): 'I think that the force is sufficient ( $\dot{\alpha} \pi о \chi \rho \tilde{\eta} v)$ '; Lysias (fr. 288 Carey, modified)

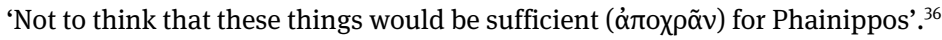

In the manuscripts of Pseudo-Zonaras' lexicon the quotation from Lysias contains the infinitive $\alpha$ ส $о \chi \rho \tilde{\alpha} v$, which clearly is at odds with standard Attic practice. Alpers (ad Orus fr. 13) keeps this reading, since it is coherent with the lemma, which seems to advise readers that both forms of the infinitive were possible in Attic. However, nothing prevents us from thinking that this is a later interpretation driven by the desire to justify the post-Classical development of the verb and guided by a wrong reading: the fragment is not quoted elsewhere, and Lysias seems to have always employed $\chi \rho \tilde{\eta} \nu, \chi \rho \tilde{\eta} \sigma \theta \alpha$ เ and compounds. ${ }^{37}$

Another source which may have been interested in tracing a post-Classical usage back to the Classical age is the Antiatticist, which is likely to have transmitted the lemma under (8) to the Synagoge, as the following entry suggests:

36 Carey 2007 actually has $\Phi \iota \lambda i \pi \pi \omega$, the lectio facilior transmitted by part of the manuscript tradition of Pseudo-Zonaras' lexicon: on this, see Alpers' apparatus ad Orus fr. 13.

37 This is the reason why Carey $2007 a d$ Lys. fr. 288 accepts $\alpha$ đохрп̃ $v$. 


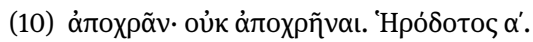

(Antiatt. \& 107 Valente)

Herodotus in the first book uses $\dot{\alpha} \pi о \chi \rho \tilde{\alpha} v$, not $\dot{\alpha} \pi о \chi \rho \tilde{\nu} \alpha \mathbf{~}$

This entry is slightly problematic for two reasons.

First, there is no infinitive $\dot{\alpha} \pi о \chi \rho \tilde{\alpha} v$ in the first book of Herodotus' Histories. The locus classicus suggested by Valente 2015 ad loc. (Hdt. 1.66.1) has the imperfect áré $\chi \rho \alpha$ instead. Since a similar discrepancy is witnessed by Phot. $\alpha 2724$ Theo-

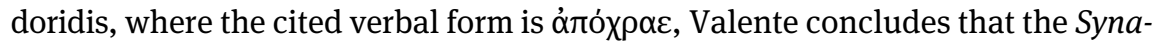
goge may have gathered some glosses "from another source rather than from a fuller version of the Antiatt.", apparently endorsing Theodoridis' view ad Phot. $\alpha$ 2724 that this gloss may originally have concerned a different verbal form. ${ }^{38}$ It is

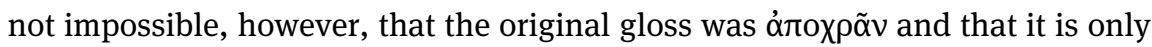
the number of the book that is wrong: the infinitive is attested in book 3 (138.2).

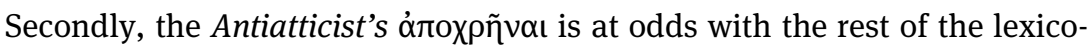
graphical tradition, which always contrasts $\dot{\alpha} \pi о \chi \rho \tilde{\alpha} v$ with $\dot{\alpha} \pi о \chi \rho \tilde{\nu} v$. We may think that $\dot{\alpha} \pi о х \rho \tilde{\eta} \nu \alpha \iota$ is a corrupted version of the original $\dot{\alpha} \pi о \chi \rho \tilde{\eta} \nu$, or take the whole lemma to be authentic. In this latter scenario, the point of the lemma may have been to contrast Herodotus' Ionic with the language of another Ionic author,

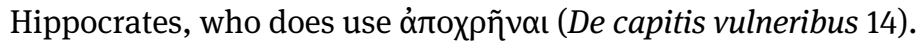

Reconstructing the Antiatticist's intentions and methodology is always a slippery path, given the customary laconic style of the epitome of this lexicon. If the suggested scenario is correct (although we will never know for sure), one may speculate that the contrast was intended to show that Herodotus did not use such

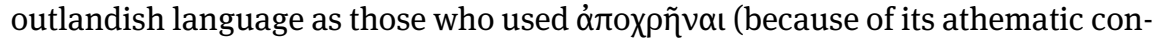
jugation), and hence that he may offer an acceptable Classical parallel for the use of the infinitive $\alpha \pi о \chi \rho \tilde{\alpha} v$, which was common in the koine. Resorting to Herodotus to justify koine forms is part of the Antiatticist's 'alternative' take on linguistic correctness, as well as proof of the special standing enjoyed by Herodotus in Imperial culture. ${ }^{39}$

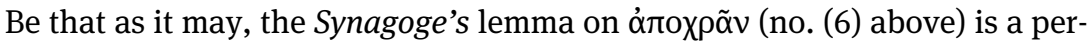
fect example to illustrate the inherent ambiguity of many lexicographical entries. It may well be that this lemma embodies my criterion (b), namely rare forms that diverged from Byzantine literary usage. At the same time, awareness of the historical evolution of Greek suggests that there may be more to this and that the

38 Valente 2015, 17-18; 19 n. 105.

39 On the Antiatticist's strategies to justify koine usages, see Cassio 2012; on Herodotus and his use in this lexicon, see Tribulato 2016, 187-191. 
lemma may also have been of interest because it went in the direction in which spoken Greek had developed (see too my comments on Orus' lemma under (9) above). The fact that the same form, $\dot{\alpha} \pi$ x $\rho \tilde{\alpha} v$, was commented upon in the Antiatticist, a text in which the selection of words is strongly oriented towards postClassical usage, further strengthens this suspicion.

\section{On Curtains, Tents and Courtyards: Or How Contemporary Language May Have Guided the Lexicographers' Interest}

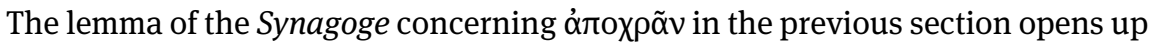
the question of the interest aroused by the Antiatticist among Byzantine lexicographers, especially the compilers of the Synagoge (broadly understood). This topic still lacks a full investigation. The information that can be gathered from textual history is meagre and can be summarized as follows:

(a) The Antiatticist has survived only in the epitome transmitted by cod. Paris. Coisl. gr. 345. This epitome may have been produced deliberately to fit the lexicographical miscellany contained in this codex.

(b) The Byzantine use of the Antiatticist is mostly limited to the Synagoge, through which much of its material passes down to Photius and the Suda. Its reception therefore seems to have been restricted to erudite circles of 8th-9th century Constantinople. ${ }^{40}$

(c) It is possible (though not proven beyond doubt) that in this period the Antiatticist may still have been circulating in other versions. Some lemmas reused in the expansions of the Synagoge, and which do not find a complete parallel in the epitome, may point in this direction (see the discussion on $\dot{\alpha} \pi$ $о \alpha \tilde{\alpha} v$ above). ${ }^{41}$ We have no idea, however, about the form and date of this other version of the Antiatticist: it may have been a majuscule copy and hence may predate the 9 th century. ${ }^{42}$

40 Valente 2015, 13. Photius and the Suda also have glosses from the Antiatticist which are not transmitted by any extant expansion of the Synagoge. It is an open question whether they used the Antiatticist independently or (as some wording typical of the Synagoge suggests) had access to a version of the Synagoge unknown to us: see Valente 2015, 25-30.

41 Valente 2015, 16.

42 Valente 2015, 18 and 21. 
(d) In spite of its limited reception and obscure history, the Antiatticist has a far from negligible presence in the Synagoge tradition as a whole: 110 out of its 841 glosses are repeated in some of the versions of the Byzantine lexicon. ${ }^{43}$

One question that would be worth investigating, in spite of the inevitable degree of speculation that it would entail, is what the compilers of the Synagoge expansions found useful in the Antiatticist. To this purpose, in this last section I consider two lemmas which may have been selected from the Antiatticist because they provided helpful information for writers of 'Byzantine' Greek who were also speakers of 'Medieval' Greek. The first lemma concerns the verb $\alpha i \rho \varepsilon \tau i \zeta \omega$ :

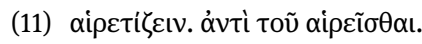

(Antiatt. $\alpha 18$ Valente)

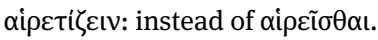

(=Com. adesp. fr. 484 K.-A.)

$\alpha i \rho \varepsilon \tau i \zeta \omega$ is an active synonym of the meaning that $\alpha i \rho \varepsilon \dot{c} \omega$ acquires in the middle: 'choose for oneself, prefer'. The short entry of the Antiatticist has not preserved a locus classicus, which Valente however restores on the basis of the following entry in the Synagoge:

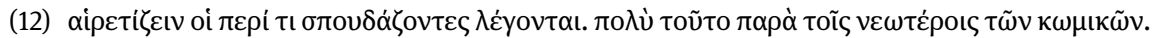

( $\Sigma^{\mathrm{b}} \alpha 648$ Cunningham)

Those who are eager about something are said to ' $\alpha i \rho \varepsilon t i \zeta \varepsilon ı v '$ This word is used very much by playwrights of New Comedy. ${ }^{44}$

There are no extant traces of the use of $\alpha i \rho \varepsilon \tau i \zeta \omega$ in New Comedy, but other sources clarify that the verb was associated with post-Classical Greek. It is prominent in the Septuagint, the Aesopic corpus and a vast array of Christian authors, and remains common in Byzantine literature. The entry in the Antiatticist (11), therefore, is consistent with this lexicon's tendency to defend post-Classical neologisms. In turn, the compiler of one of the expansions of the Synagoge may have considered the lemma interesting because it provided an ancient basis for a common usage in Medieval Greek. aipé $\omega$, which continued to be used in Byzantine

43 Valente 2015, 14. His counts are more generous than those in Cunningham 2003 (which may not be complete). See too Latte 1915, 376-377.

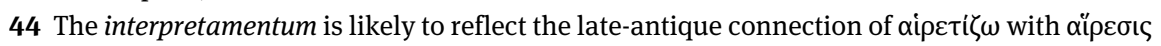
'heresy'. 
Greek, was perhaps perceived as typical of the high style, given that lexicographers and scholiasts alike often gloss it with more common verbs such as $\lambda \alpha \mu \beta \alpha \dot{v} \omega \omega, \pi \circ \rho \theta \varepsilon \dot{\varepsilon} \omega$ and кpiv $\omega$ (all of which, incidentally, have survived in Modern Greek, while aipé $\omega$ as such has not). ${ }^{45}$

Another lemma that reached the Synagoge from ancient lexica and that seems to have originally belonged to the Antiatticist is the noun aủ $\alpha$ ii $\alpha$, though in this case the transmission path seems to have been much more complicated and probably affected by the interference between Classical and Christian Greek,

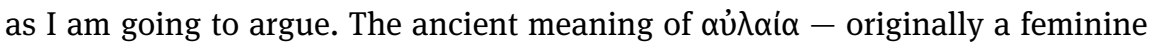
adjective derived from $\alpha \dot{ } \lambda^{\prime}$ ' 'courtyard, open space' - is 'curtain' (i.e. the thing that encloses an open space) and more generally a 'hanging piece of cloth' ${ }^{46}$ The Antiatticist ((13) below) was interested in this word and its meaning, while a parallel entry in Pollux ((14) below) provides a fuller context, as well the locus classicus (Hyp. fr. 139 Jensen):

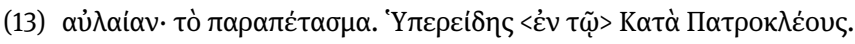

(Antiatt. a 135 Valente)

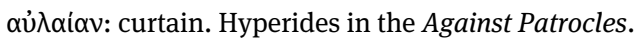

(14)

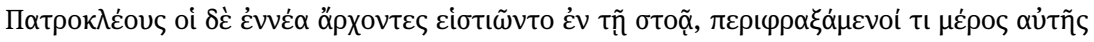

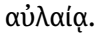

(Poll. 4.122 Bethe)

It is also possible to call the curtain $\alpha \dot{u} \lambda \alpha i \alpha$, given that Hyperides in the oration Against Patrocles says 'the nine archonts took their meals in the stoa, screening off a part of it with a curtain'.

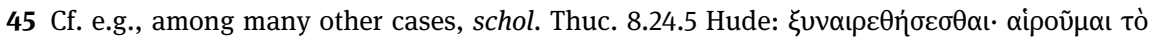

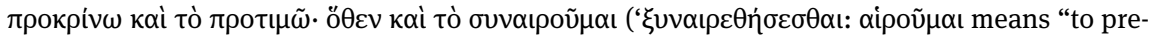
fer" and "to esteem"; from this also [derives] ouvaıpoũ $\mu \alpha$ ').

46 The first attestations of this word go back to the 4th century BC: apart from Menander (fr. 454 K.-A., cf. text under (19) below), see Theophr. Char. 5.9.4 (a piece of embroidered tapestry); Phylarchus FGrHist 2 F 41, quoted by Athen. 12.539c-540a (large pieces of cloth used to enclose wild beasts in a military camp); Polyb. fr. 22 Büttner-Wobst, transmitted by Suda $\alpha 4434$ Adler (a curtain behind which one can hide and eavesdrop). The best lexicographical collection of works in which $\alpha \dot{\nu} \lambda \alpha i \alpha$ is used remains the entry in Hase's edition of Stephanus' ThGL. An overview of

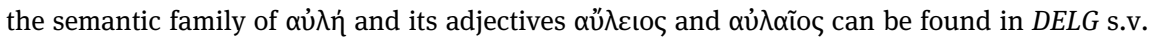
$\alpha u ̉ \lambda$. Many of the lemmas in Greek lexica reflect contamination and confusion between the two adjectives: see Section 5 below. 
The following entries from the Synagoge, however, narrow down the meaning of $\alpha \dot{\lambda} \lambda \alpha i \alpha$ by adding the genitive $\tau \tilde{\eta} \varsigma$ $\sigma \kappa \eta \nu \tilde{\eta} \varsigma$ to $\pi \alpha \rho \alpha \pi \varepsilon \dot{\tau} \alpha \sigma \mu \alpha$ :

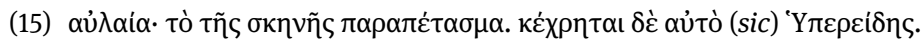

( $\Sigma \alpha 1091$ Cunningham)

$\alpha \cup ̉ \lambda \alpha i \alpha$ : curtain of the tent. Hyperides used it.

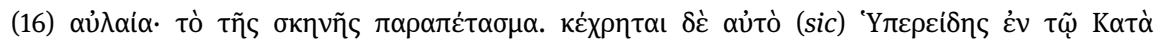

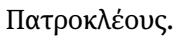

( $\Sigma^{\mathrm{b}} \alpha 2405$ Cunningham)

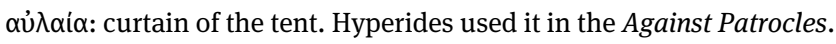

The presence of the title of Hyperides' oration in $\Sigma^{\mathrm{b}}$ (16), which $\Sigma$ (15) lacks, is further evidence of the fact that the compiler of $\Sigma^{\mathrm{b}}$ had direct access to the Antiatticist, which also preserves the title of the oration. ${ }^{47}$ The addition of the genitive

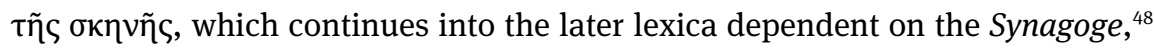
seems to have had its first origin in Cyril's lexicon (5th cent. AD). This is testified by the readings in some of the manuscripts of this work, although given the lack of a complete edition of Cyril's lexicon the relevant information can be only reconstructed from the parallel lemma in Hesychius' lexicon:

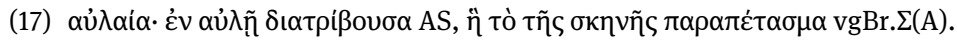

(Hsch. $\alpha 8282$ Latte/Cunningham)

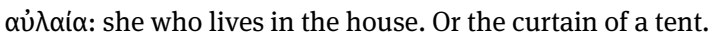

Faced with the different interpretamenta of aủ $\lambda \alpha i \alpha$ in all these lexica, it is natural to ask why the specification $\tau \tilde{\eta} \varsigma$ $\sigma \kappa \eta \nu \tilde{\eta} \varsigma$ was added (perhaps originally by Cyril) and kept in Byzantine lexicography, in contrast to earlier Atticist lexica, the extant versions of which it is absent from. The answer lies in the exact meaning of this genitive, which can in principle be interpreted either as 'of the tent' (the translation adopted here) or 'of the stage'.

47 The lemma in $\Sigma^{\mathrm{b}}$ must go back to the expansion named $\Sigma^{\prime}$ by Cunningham 2003, 687, which was the common source of the two other expansions $\left(\Sigma^{\prime \prime}\right.$ and $\left.\Sigma^{\prime \prime \prime}\right)$ used independently by the Suda (sometimes also Photius) and $\Sigma^{\mathrm{b}}$ : see n. 25.

48 Phot. $\alpha 3169$ Theodoridis; Suda a 4434 Adler; Etym. Magn. a 2087 Lasserre/Livadaras. In Phot. $\alpha 3169$ Theodoridis the interpretamentum is abbreviated, as is usually the case with glosses contained only in cod. Zavordensis $95(=\mathrm{z})$ : the traces of Hyperides' name present on the margin allow Theodoridis to supply the omitted parts from $\Sigma^{\mathrm{b}}$ and the $S u d a$. 
At first sight, the latter meaning may seem appropriate to the context of Pollux's passage (no. (14) above), which deals with the parts of the theatre, and hence it may seem the most likely to be ancient. However, this particular chapter of Pollux does not deal with the oknvin and, as noted by Park Poe 2000, 247 "the example of an $\alpha \dot{\lambda} \lambda \alpha i \alpha$ which is cited refers to a curtain hanging in a colonnade, whose purpose was to screen off a meeting of the archons".$^{49}$ If the specification $\tau \tilde{\eta} \varsigma \sigma \kappa \eta v \tilde{\eta} \varsigma$ therefore goes back to a later source than Pollux or the Antiatticist, its translation as 'of the stage' is at odds with everything we know about the meaning of $\alpha \dot{\lambda} \lambda \alpha i \alpha$ in post-Classical Greek, where it certainly does not identify a stage curtain (which is called $\pi \alpha \rho \alpha \pi \varepsilon$ ć $\alpha \mu \alpha$ instead). ${ }^{50}$ Nor does it seem probable that these Byzantine lexica wished to comment on the Latin word aulaeum 'stage curtain', originally of course a Greek calque: they are clearly interested in documenting Ancient Greek usages.

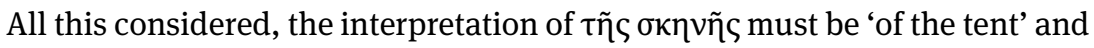
the reason probably lies in the nature of Cyril's lexicon which, as far as we can ascertain, was the first to introduce it. This work, which was an important source for the Synagoge, is known for adding many Biblical glosses to earlier lexicographical material, in many cases words that the same Cyril used in his religious writings. ${ }^{51}$ Indeed, the interpretation of $\alpha \dot{\lambda} \lambda \alpha i \alpha$ as a 'curtain hanging from a tent' can only be understood by taking into account the semantics of the word in Old Testament Greek, where it is usually employed in this narrower meaning. This is particularly the case in the chapters of Exodus describing the construction of the sacred tabernacle, as in the passage below:

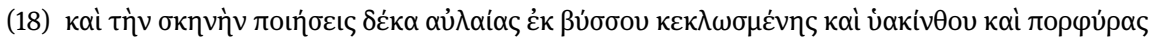

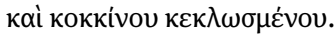

(Exodus 26.1)

And you shall make the tent with ten curtains from twisted linen and blue and purple and twisted scarlet. (transl. L.J. Perkins, NETS).

49 Park Poe 2000, 248 also rules out that this theatrical application of aủ $\alpha$ ía was present in the Onomasticon, since it would have been more appropriate to refer to it in the chapters "concerned with the scenic background" (124-126).

50 It is worth mentioning that $\alpha$ ט̉ $\alpha$ í $\alpha$ is now the standard Modern Greek form for 'stage curtain'. It is, however, a learned resuscitation (see the abbreviation " $\lambda$ 'y." = 'learned' in $L K N$ s.v.) with no history in Medieval Greek.

51 This was first detected by Wendel: see now Corcella 2017. 
These chapters of Exodus are often quoted in late-antique and Byzantine Christian exegesis, a fact which partly explains the lexicographical interest in the specific meaning of $\alpha \dot{u} \lambda \alpha i \alpha$ in this context. ${ }^{52}$ An example is chapter 26 of Cosmas Indicopleustes' Christian Topography, in which the 6th-century author describes Moses' construction of the tabernacle and glosses $\alpha \dot{v} \lambda \alpha i \alpha$ with the Latin calque кортiva 'curtain', probably a more common word for 'curtain' in low-register Greek: ${ }^{53}$

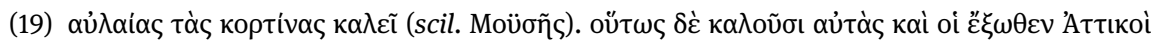

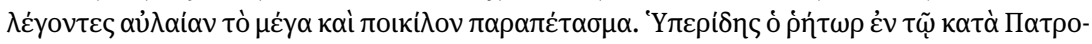

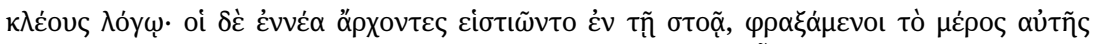

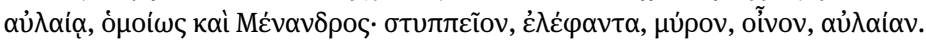

(Cosmas Indicopleustes, Topographia Christiana 5.26 Wolska-Conus)

[Moses] calls the curtains $\alpha \dot{\lambda} \lambda \alpha i$ as: non-Attic speakers too call the curtains in this way, using $\alpha$ vं $\alpha$ í $\alpha$ to refer to a large and many-coloured curtain. Hyperides, the orator, [said] in the Against Patrocles: 'the nine archonts took their meals in the stoa, screening off a part of it with a curtain'. Similarly Menander [says]: ‘flax, ivory, perfume, wine, curtain' (fr. 454 K.-A.).

In Cosmas we have an important link between the Atticist tradition, which has handed down $\alpha \dot{\lambda} \lambda \alpha i \alpha$ as a synonym of $\pi \alpha \rho \alpha \pi \varepsilon \dot{\tau} \alpha \sigma \mu \alpha$ and illustrated it with a reference from Hyperides, and Biblical exegesis. He makes a connection between the language of the Old Testament and that of those who 'do not speak standard

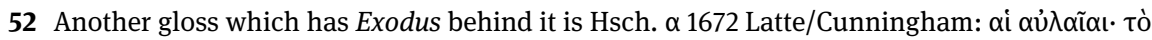
$\kappa \alpha \tau \alpha \kappa \alpha \dot{\lambda} \lambda \nu \mu \mu \alpha$ (' $\alpha u ̉ \lambda \alpha \tilde{a} \alpha$ : the veil'). The Latte/Cunningham edition adds, as a locus classicus, Exodus 37.14, another passage concerned with the building of the sacred tabernacle. However,

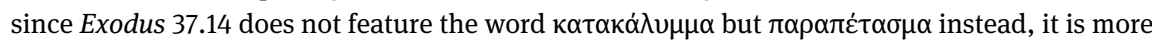
probable that the locus classicus behind this gloss is the same as that behind $\alpha 8282$ discussed

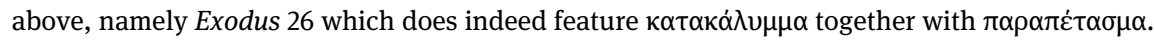
Cunningham further classifies the entry with the abbreviation "LXX", which identifies glosses concerned with Biblical passages. It seems to me that both glosses, concerned with the meaning

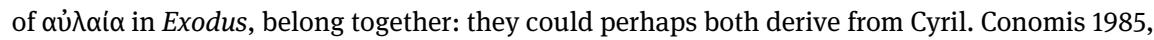
344-345 argues that the original gloss had nothing to do with curtains ( $\alpha \dot{\lambda} \lambda \tilde{\alpha} \alpha \mathrm{l}$ ) and referred to the neuter plural $\alpha$ $\lambda_{\iota} \alpha$ ('country-house, fold, stable, cave') instead. He also proposes that the

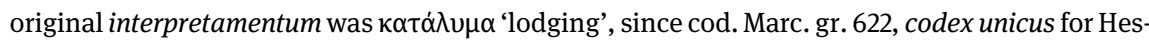

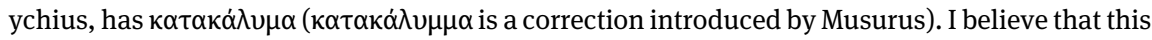

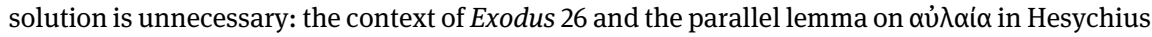
prove that the lexicographical interest lied in explaining the special meaning of this word in Biblical Greek.

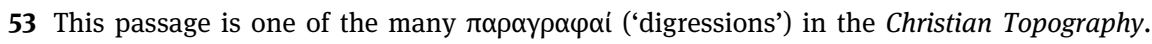
These are generally thought to have been added by Cosmas himself: see Wolska-Conus 1968, 67. 


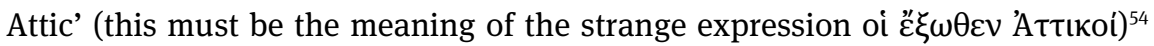
and this fact gives us a clue about why aủ $\alpha$ í $\alpha$ entered Atticist lexicography in the first place. It was probably one of those words which were common in postClassical Greek but had a shaky Classical pedigree and for which Pollux and the Antiatticist could find no better authority than Hyperides. Cosmas must have used an Atticist source concerned with justifying or condemning a post-Classical usage which resorted to quoting Menander instead: his standing in the Atticist canon notoriously is equally shaky.

Such detailed lexicographical interest in $\alpha \dot{\lambda} \lambda \alpha i \alpha$ therefore reflects first and foremost the dichotomy between Classical and post-Classical Greek. At the same time, it is also to be viewed in the context of Greek linguistic history. In Byzantine Greek, the primary meaning of $\alpha$ vं $\alpha$ í $\alpha$ was no longer 'curtain' (of whatever kind): a series of semantic shifts and analogical processes had brought it to mean 'tent' or 'courtyard'. The earliest evidence of the semantic shift by which $\alpha \dot{\lambda} \lambda \alpha i \alpha$ came to be used as a synecdoche for 'tent' belong to Isaiah 54 ('the restoration of Israel'), where $\alpha \dot{\nu} \lambda \alpha i ́ \alpha$ features as a variatio for $\sigma \kappa \eta v \eta$ :

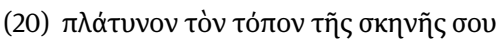

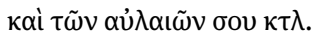

(Isaiah 54.2)

Enlarge the site of your tent

and of your curtains, etc. (transl. M. Silva, NETS)

Quotations of these lines abound in Christian authors and it is very likely that in some registers of Greek it was normal to employ aủ $\alpha$ ía to say 'tent' already in the early Byzantine period. Indeed, Cosmas Indicopleustes' careful annotations concerning the semantics of the word are already intended to guide readers of the Scriptures who may be confused by these competing meanings. Outside Biblical

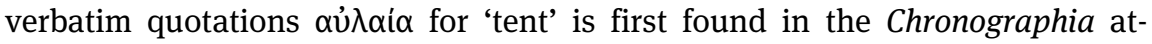
tributed to the so-called Theophanes Continuatus. A passage of book 4, the original compilation of which goes back to the late 9th century, describes the setting up of the camp of Emperor Michael III by using oknvai to refer to the tents in a general way, and then $\alpha \dot{\lambda} \lambda \alpha i \alpha$ for Michael's tent in particular: $:^{55}$

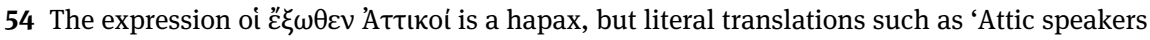
from abroad' or 'non-Attic speakers' are clearly out of context: cf. also Wolska-Conus 1970, 48 ("les gens du dehors atticistes").

55 The word is used again in Chronographia 5.236.2 Bekker (= 17.8 Ševčenko), where it appears

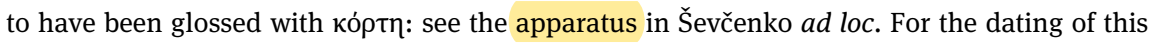
composite text, and particularly of the first four books, see Featherstone/Codoñer 2015, 14. 


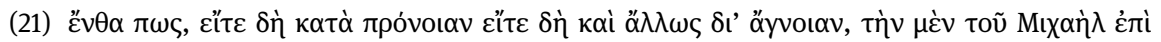

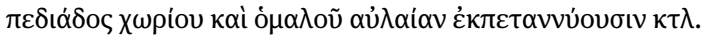

(Theophanes Continuatus, Chronographia 4.41.15-16

Featherstone/Codoñer $=4.205 .4$ Bekker)

Somehow, whether by Providence or else through ignorance, they pitched the tent of Michael on a plain and level ground, etc.

Other evidence for this semantic shift comes from Theodore Prodromus (12th century) who alludes to Isaiah in his exhortation for Byzantium to multiply its dominions:

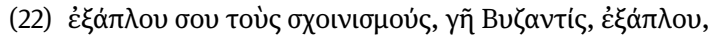

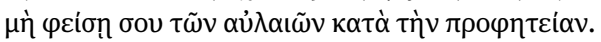

(Theodorus Prodromus, Carmina historica

11.131-132 Hörandner)

Spread out your dominions, Byzantium: do not spare your tents, as in the prophecy.

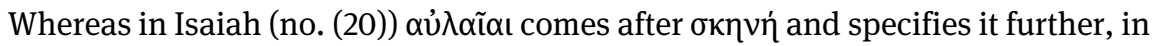
Teophanes Continuatus and Theodore Prodromus the word has become 'tent' tout court. In this meaning $\alpha \dot{\lambda} \alpha \alpha i \alpha$ is used by a variety of later Byzantine sources both in passages which variously refer to the Scripture and in others where the context is not religious. ${ }^{56}$

The picture, however, is further complicated by the fact that at some point in Byzantine linguistic history $\alpha \dot{\jmath} \lambda \alpha i \alpha$ seems to have been used also as a synonym of $\alpha \dot{u} \lambda \eta$ ' courtyard', the noun from which it originally derived. The most authoritative source on this semantic equivalence is Eustathius, who overtly comments on this usage and explains its motivation with a general morphological rule which he devises on the basis of analogy:

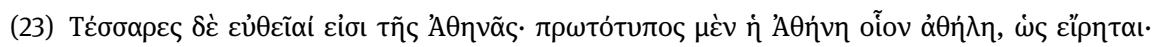

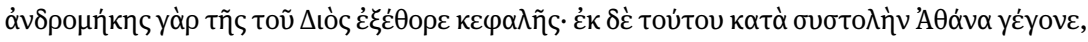

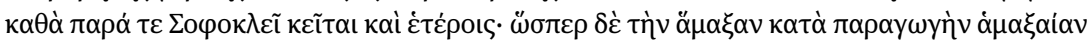

56 See for instance Michael Italicus' letter 23 (174.20 Gautier) and the two attestations in Nicephorus Basilakes' letters from his exile, where $\alpha \dot{\lambda} \lambda \alpha i \alpha$ serves both as an allusion to the Biblical exodus and as a sarcastic description of the poor state of Nicephorus' current abode: Epistulae 1.18

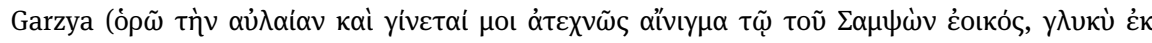

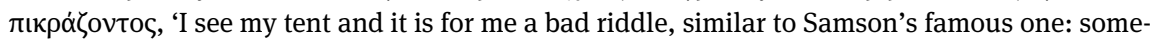

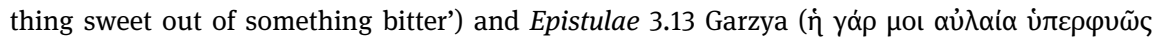

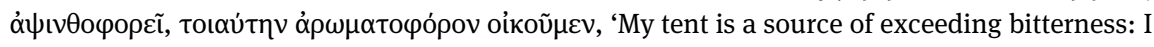
live in such a tomb!'). For the context of Nicephorus' exile, see Wirth 1966. 
Making the Case for a Linguistic Investigation of Greek Lexicography: Some Examples from the Byzantine Reception of Atticist Lemmas

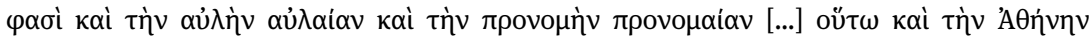

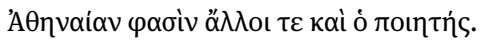

(Eust. Il. 1.32.28-31 van der Valk)

The nominative of (the name) Athena has four forms. The original one is 'A $\theta$ ńvn, which is to say $\alpha \dot{\theta} \dot{\lambda} \lambda \eta$ ('unsuckled'): for she sprang from Zeus' head already in an adult's form. The form 'A $\theta$ óvo has derived from this name by vowel mutation: it is attested in Sophocles and other authors. In the same way as they (i.e. Attic-speakers) call the cart ( $(\ddot{\alpha} \mu \alpha \xi \alpha) \dot{\alpha} \mu \alpha \xi \alpha \dot{\alpha} \alpha$ by

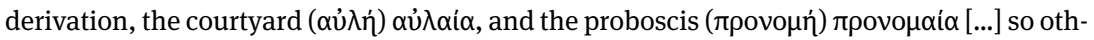
ers and Homer also call Athena 'Änvoía.

Eustathius himself used $\alpha \dot{\lambda} \lambda \alpha i \alpha$ as 'courtyard' in his pamphlet De emendanda vita monachica, where the expression " courtyard of the houses of common people: the danger which awaits the monk who ventures out of his cloister (152.10 Metzler). ${ }^{57}$ The language of this pamphlet has been described as typical of the Byzantine 'elaborated style', rich in neologisms and hapax legomena, and intended for educated readers..$^{58}$ The fact that in his commentary on the Iliad Eustathius comments on the morphological deriva-

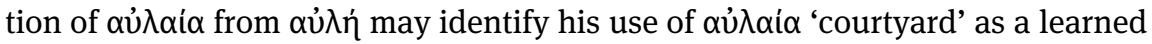
element. Yet the attestations and the history of this meaning suggest that in this particular case Eustathius may be indulging in the lower register.

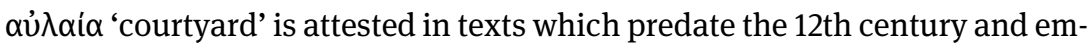
ploy a lower register than Eustathius. The first of these texts is the anonymous Life of Saints David, Symeon and George of Mytilene, which van den Gheyn 1899, 210 dated to the end of the 9th or the beginning of the 10th century. aủ $\lambda$ aí occurs in a parable narrating how St. George calmed down a noisy donkey tied in the courtyard which was disturbing the final hour of a sick man:

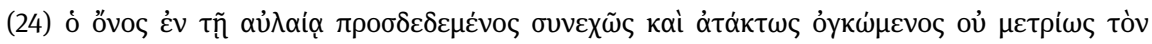

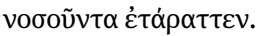

(Vita sanctorum Davidis, Symeonis et Georgii Mitylenae 242.22-24 van den Gheyn)

The ass, which had been tied in the courtyard for a long time and was exceedingly excited, disturbed the sick man a lot.

57 Metzler 2006a, 168 does not register any variant in her apparatus: the reading $\alpha \dot{\lambda} \lambda \alpha i$ á, therefore, is probably authentic.

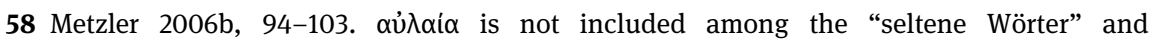
“Sonderbedeutungen” by Metzler 2006b, 103. 
Of course, one cannot be absolutely certain that this usage of $\alpha \dot{\lambda} \lambda \alpha i \alpha$ can be ascribed to the original layer of this hagiographical text, nor that the dative $\varepsilon v \tau \tilde{n}$

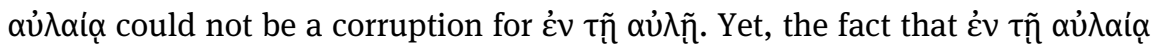
may be authentic is suggested by the independent attestation of the hapax $\pi \rho o \alpha v \lambda \alpha i \alpha$ in John Cameniates' The Capture of Thessaloniki (51.2.2 Böhlig), dated to the early 10th century. Both attestations may suggest that the confusion between $\alpha \dot{u} \lambda \alpha i \alpha$ and $\alpha \dot{\lambda} \lambda \dot{n}$ arose in the lower registers of Byzantine Greek, entered hagiographical texts and chronicles first, and later spread to higher registers. To-

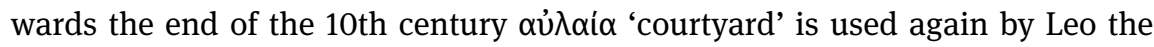
Deacon in a passage of his History which describes the famous siege of Dorystolon:

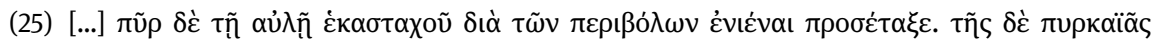

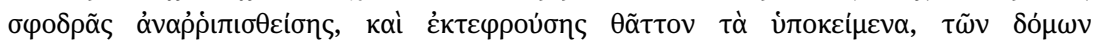

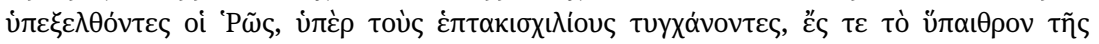

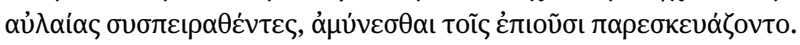

(Leo Diaconus Historia 137.10-15 Hase) $)^{59}$

[... the emperor] ordered to set fire to the palace on all sides by using fire-balls. ${ }^{60}$ Since a violent conflagration took place and it quickly reduced the underlying structures to ashes, the Rus', who happened to be more than seven thousand in number, came out of the buildings and crowded together in the open part of the courtyard, getting ready to fend off those who advanced. ${ }^{61}$

Leo first describes the way the fortified palace ( $\alpha \dot{u} \lambda \dot{n}$ ) was set on fire. He then

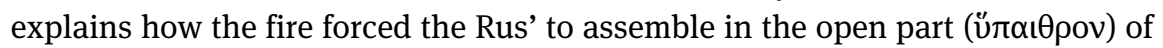
the courtyard ( $\alpha \dot{\nu} \lambda \alpha i \alpha$ ). These three words are not used to achieve variatio, but to let the reader picture the subsequent effects of emperor John Tzimiskes I's orders: the seven thousand Rus' are forced to leave their shelter and crowd in an open and undefended part of the fort.

The attestations of $\alpha \dot{\lambda} \lambda \alpha i \alpha$ in (23-25) above prove not only the semantic shift undertaken by the word, but also another more general fact: the easy contamina-

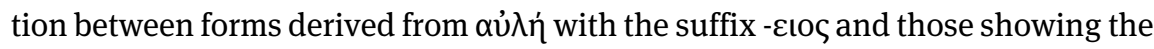

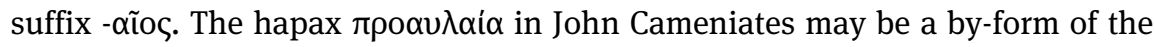
more common $\pi \rho 0 \alpha u ́ \lambda ı v$ ('courtyard, space before a cattle-pen'), which in Byzantine Greek could sometimes take the form $\pi \rho o \alpha u ́ \lambda \varepsilon ı$ (feminine) and which

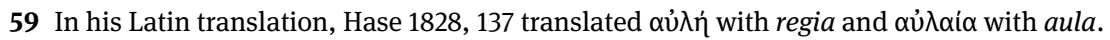

60 Hase 1828, 137 translates 'per propugnancula'. Talbot/Sullivan 2005, 183 n. 42 (followed here) assume that $\pi \varepsilon \rho ı \beta$ ó $\lambda \omega v$ is corrupt for $\pi \nu \rho ı \beta o ́ \lambda \omega \nu$.

61 Translation adapted from Talbot/Sullivan 2005, 202. 


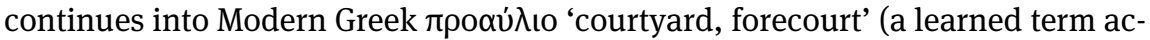
cording to $L K N$ ). It may also be the case that these forms were confused because of their pronunciation in some registers of Byzantine Greek. In learned registers the feminine $\alpha \dot{\lambda} \lambda \varepsilon i \alpha$ '(outer) door' kept its original proparoxytone accentuation and could therefore have the same pronunciation as properispomenon adjectives

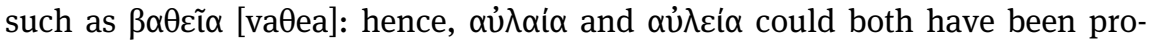
nounced [avlea]. ${ }^{62}$

\subsection{Concluding Remarks on $\alpha u ̉ \lambda \alpha i ́ \alpha$}

This review of the use of $\alpha \dot{\lambda} \lambda \alpha \dot{\alpha} \alpha$ across the centuries places the lexicographical entries pertaining to this word (texts (15-17) above) in a new light. It would be unsatisfactory to think that the Synagoge, Photius or even Hesychius are merely concerned with the meaning of $\alpha \dot{\lambda} \lambda \alpha i \alpha$ in a Classical author, Hyperides, who was no longer read in Byzantine times. ${ }^{63}$ On the contrary, as I have argued, these lexicographical entries do not describe the Classical meaning of aủ $\alpha$ aí (i.e. $\pi \alpha \rho \alpha \pi \dot{\tau} \tau \alpha \sigma \mu \alpha$ : see Pollux and the Antiatticist under (13-14) above), but the spe-

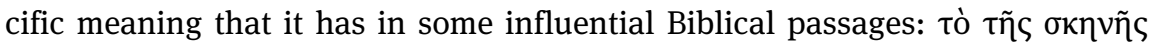

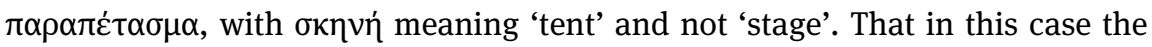
lexicographers' interest was in semantic variation in Christian Greek is further

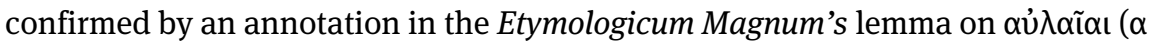

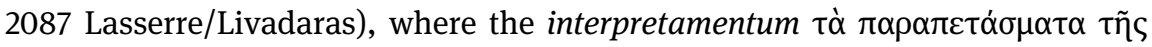

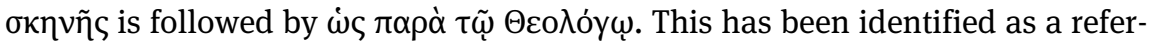

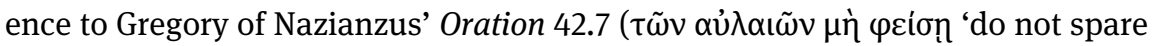
your tents'), where, however, the theologian is simply referring to Isaiah 54 . Hyperides' name then seems to have been passed down as a relic from one lexicographical tradition that was interested in commenting on a word associated with the koine in relation to a specific Attic custom (that of separating the stoa with a

62 This is likely to have been different in vernacular varieties, where no accent shift is observed in the feminine: hence, $\alpha \hat{\nu} \lambda \varepsilon\llcorner\alpha$ would differ from $\alpha \dot{\lambda} \lambda \alpha i \alpha$. Apart from the different accent, propa-

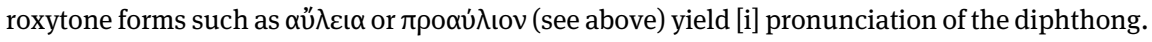

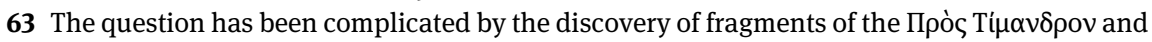
of the Прò $\Delta \iota \dot{\omega} v \delta \alpha v$ in the so-called Archimedes' palimpsest (Tchernetska 2005; Ucciardello 2009). In his up-to-date overview of Hyperides' post-Classical transmission Ucciardello 2012a, 305 concludes that he was "una rarità a Bisanzio" and that he probably circulated only in anthologies destined for the classroom. He also rules out the possibility that quotations from Hyperides in Byzantine rhetoric and lexicography testify to the direct use of Hyperides' text in Byzantium (Ucciardello 2012a, 321). 
curtain), to another lexicographical tradition interested in the meaning that the word had in the completely different context of Old Testament Greek.

The relevance of these words for Byzantine lexicographers can only be fully appreciated if they are placed in the historical and linguistic context that preserved them. In this particular case Byzantine scholars were not only torn between the different linguistic models set by the Classics and the Scripture, but also between older meanings and the contemporary linguistic reality, where $\alpha u ̉ \lambda \alpha i \alpha$ meant 'tent' or 'courtyard', but apparently not 'curtain'. This situation is clearly exemplified by the language used by Nicetas Choniates in his Chronicle, where $\alpha \dot{\lambda} \lambda \alpha i \alpha$ sometimes identifies a tent (e.g. in 41.15 and 197.29 van Dieten) and sometimes a courtyard (as in 236.10 and 237.1 van Dieten). It is probable that by the 8th century to use $\alpha \dot{u} \lambda \alpha i$ í for 'curtain' was an erudite touch and it is to be concluded that the ancient meaning had died out.

\section{Conclusions}

The case-studies presented in this paper all contribute to illustrate how, through different linguistic situations, the application of a historical linguistic approach allows us to analyze the Byzantine lexicographical tradition in a more nuanced way and to prove that its re-use of older material is not simply uncritical recycling, but is motivated by the linguistic situation of the time. Many of the lemmas contained in Byzantine lexica can be interpreted as instructions to educated speakers and writers, who lived in a situation of linguistic diglossia, on how to fine-tune their use of language in the light of a linguistic evolution which may have distanced it from both the Classics and the Scripture. If brought up to the level of systematic studies, piecemeal lexical investigations such as those provided in this paper are likely to achieve a more fine-grained appreciation of Byzantine Greek which, going beyond the classic diglossic dichotomy between high and low language, takes into account the high level of register mixing in Byzantine texts and does justice to the language of the Byzantines: a live variety, and not simply a sterile reproduction of earlier linguistic stages. 
Making the Case for a Linguistic Investigation of Greek Lexicography: Some Examples from the Byzantine Reception of Atticist Lemmas

\section{Bibliography}

Alpers, K. (1990), “Griechische Lexikographie in Antike und Mittelalter: Dargestellt an ausgewählten Beispielen”, in: H.A. Koch (ed.), Welt und Information: Wissen und Wissenvermittlung in Geschichte und Gegenwart, Stuttgart, 14-38.

Alpers, K. (2001), “Lexikographie, griechische”, in: G. Ueding (ed.), Historisches Wörterbuch der Rhetorik, vol. 5, Tübingen, 194-210.

Bakker, E.G./de Jong, I.J.F./van Wees, H. (eds.) (2002), Brill's Companion to Herodotus, Leiden/ Boston/Köln.

Beck, H.-G. (1971), Geschichte der byzantinischen Volksliteratur, München.

Bethe, E. (1900), Pollucis Onomasticon, vol. 1, Leipzig.

Böhlig, G. (1956), Untersuchungen zum rhetorischen Sprachgebrauch der Byzantiner, mit besonderer Berücksichtigung der Schriften des Michael Psellos, Berlin.

Browning, R. (1992), “The Byzantines and Homer”, in: R. Lamberton/J.J. Keaney (eds.), Homer's Ancient Readers, Princeton, 134-148.

Carey, C. (2007), Lysiae orationes cum fragmentis, Oxonii.

Cassio, A.C. (2012), “Intimations of Koine in Sicilian Doric”, in: O. Tribulato (ed.), Language and Linguistic Contact in Ancient Sicily, Cambridge, 251-264.

Cassio, A.C. (2014), “Lessico 'moderno' nei testi greci antichi: Storie di continuità e discontinuità”, in: C. Carpinato/0. Tribulato (eds.), Storia e storie della lingua greca, Venezia, $35-48$.

Cohn, L. (1900), “Griechische Lexikographie”, in: K. Brugmann (ed.), Griechische Grammatik, 3rd edn., München, 577-616.

Conomis, N.C. (1985), “Lexicographical Notes”, in: BZ 78, 344-349.

Corcella, A. (2017), “Le trappole di Cirillo: Hesych. $\varepsilon 4016$ L., $\pi 12$ H.”, in: Eikasmos 28, 225-234.

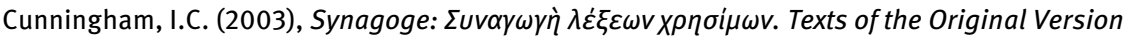
and of Manuscript $B$, Berlin/New York.

Cuomo, A.M. (2017), “Medieval Textbooks as a Major Source of Historical Sociolinguistic Studies of (High-Register) Medieval Greek", in: Open Linguistics 3, 442-455.

de Leeuw, M. (2000), “Der Coislinianus 345 im Kloster Megisti Lavra (Athos)”, in: ZPE 131, 58-64.

Dewald, C./Marincola, J. (eds.) (2006), The Cambridge Companion to Herodotus, Cambridge. Dover, K.J. (1968), Aristophanes: Clouds. Edited with Introduction and Commentary, Oxford. Erbse, H. (1950), Untersuchungen zu den attizistischen Lexika, Berlin.

Featherstone, M./Codoñer, J.S. (2015), Chronographiae quae Theophanis Continuati nomine fertur: Libri I-IV, Boston/Berlin.

Hase, C.B. (1828), Leoni Diaconi Caloënsis historiae libri decem, Bonnae.

Hatzidakis, G.N. (1892), Einleitung in die neugriechische Grammatik, Leipzig.

Hinterberger, M. (ed.) (2014), The Language of Byzantine Learned Literature, Turnhout.

Hörandner, W./Trapp, E. (eds.) (1991), Lexicographica Byzantina, Wien.

Horrocks, G.C. (2014), “High-Register Medieval Greek”, in: C. Carpinato/O. Tribulato (eds.), Storia e storie della lingua greca, Venezia, 49-72.

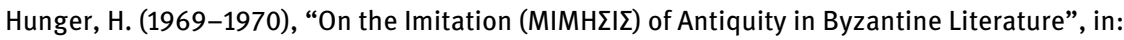
Dumbarton Oaks Papers 23-24, 15-38.

Hunger, H. (1978), Die hochsprachliche profane Literatur der Byzantiner, München. 
Hunger, H. (1991), "Was nicht in der Suda steht, oder: Was konnte sich der gebildete Byzantiner des 10./11. Jahrhunderts von einem «Konversationslexikon» erwarten?”, in: W. Hörandner/E. Trapp (eds.), Lexicographica Byzantina, Wien, 137-153.

Kaldellis, A. (2007), Hellenism in Byzantium: The Transformations of Greek Identity and the Reception of the Classical Tradition, Cambridge/New York.

Kaldellis, A. (2012), "The Byzantine Role in the Making of the Corpus of Classical Greek Historiography: A Preliminary Investigation”, in: JHS 132, 71-85.

Kühner, R./Blass, F. (1892), Ausführliche Grammatik der griechischen Sprache, vol. 1.2: Elementar- und Formenlehre, 3rd edn., Hannover/Leipzig.

Latte, K. (1915), “Zur Zeitbestimmung des Antiatticista”, in: Hermes 50, 373-394.

Lemerle, P. (1971), Le premier Humanisme byzantine: Notes et remarques sur enseignement et culture à Byzance des origines au Xe siècle, Paris.

Manolessou, I. (2014), “Learned Byzantine Literature and Modern Linguistics”, in: M. Hinterberger (ed.), The Language of Byzantine Learned Literature, Turnhout, 13-33.

Matthaios, S. (2006), "Suda: The Characters and Dynamics of an Encyclopedic Byzantine Dictionary”, in: J.N. Kazazis (ed.), $н \lambda \varepsilon \xi ı$

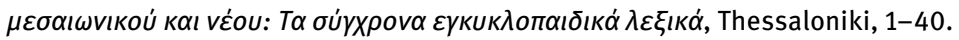

Matthaios, S. (2010), “Lexikographen über die Schulter geschaut: Tradition und Traditionsbruch in der griechischen Lexikographie”, in: M. Horster/C. Reitz (eds.), Condensing Texts Condensed Text, Stuttgart, 165-207.

Matthaios, S. (2013), “Pollux’ Onomastikon im Kontext der attizistischen Lexikographie: Gruppen «anonymer Sprecher» und ihre Stellung in der Sprachgeschichte und Stilistik”, in: C. Mauduit (ed.), L'Onomasticon de Pollux: Aspects culturels, rhétoriques et lexicographiques, Lyon, 67-140.

Matthaios, S. (2015), "Zur Typologie des Publikums in der Zweiten Sophistik nach dem Zeugnis der Attizisten: ,Zeitgenössische“ Sprechergruppen im Onomastikon des Pollux”, in: M. Tziatzi/M. Billerbeck/F. Montanari/K. Tsantsanoglou (eds.), Lemmata: Beiträge zum Gedenken an Christos Theodoridis, Berlin/Boston, 286-313.

Mayser, E. (1923), Grammatik der griechischen Papyri aus der Ptolemäerzeit, vol. 1: Laut- und Wortlehre, 2nd edn., Berlin/Leipzig.

Meillet, A. (1930), Aperçu d'une histoire de la langue grecque, 3rd edn., Paris.

Metzler, K. (2006a), Eustathii Thessalonicensis De emendanda vita monachica, Berlin/New York.

Metzler, K. (2006b), Eustathios von Thessalonike und das Mönchtum: Untersuchungen und Kommentar zur Schrift De emendanda vita monachica, Berlin/New York.

Monaco, C. (2015), La lingua di Menandro nell'interpretazione dei lessicografi greci, diss. Roma.

Moulton, J.H. (1908), A Grammar of New Testament Greek, vol. 1: Prolegomena, 3rd edn., Edinburgh.

Pontani, F. (2015), “Scholarship in the Byzantine Empire (529-1453)", in: F. Montanari/S. Matthaios/A. Rengakos (eds.), Brill's Companion to Ancient Greek Scholarship, 2 vols., Leiden/New York, 297-455.

Priestley, J./Zali, V. (eds.) (2016), Brill's Companion to the Reception of Herodotus in Antiquity and Beyond, Leiden/Boston.

Pritchett, W.K. (1956), “The Attic Stelai: Part II”, Hesperia 25, 178-317.

Reinhold, H. (1898), De Graecitate patrum apostolicorum librumque apocryphorum Novi Testamenti quaestiones grammaticae, Halis Saxonum. 
Making the Case for a Linguistic Investigation of Greek Lexicography: Some Examples from the Byzantine Reception of Atticist Lemmas 269

Reitzenstein, R. (1897), Geschichte der griechischen Etymologika, Leipzig.

Reitzenstein, R. (1907), Der Anfang des Lexikons des Photios, Leipzig/Berlin.

Robins, R.H. (1993), The Byzantine Grammarians: Their Place in History, Berlin/New York.

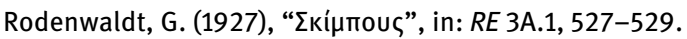

Rollo, A. (2008), “Greco ‘medievale’ e greco ‘bizantino”, in: AION(ling.) 30, 429-473.

Schweizer, E. (1898), Grammatik der pergamenischen Inschriften: Beiträge zur Laut- und Flexionslehre der gemeingriechischen Sprache, Berlin.

Ševčenko, I. (1981), “Levels of Style in Byzantine Prose”, in: JÖB 31, 289-312.

Talbot, A.-M./Sullivan, D.F. (2005), The History of Leon the Deacon: Byzantine Military Expansion in the Tenth Century, Washington D.C.

Tchernetska, N. (2005), “New Fragments of Hyperides from the Archimedes Palimpsest”, in: ZPE 154, 1-6.

Tolkiehn, J. (1925), “Lexikographie”, in: RE 12.2, 2432-2482.

Tosi, R. (2015), “Typology of Lexicographical Works”, in: F. Montanari/S. Matthaios/ A. Rengakos (eds.), Brill's Companion to Ancient Greek Scholarship, 2 vols., Leiden/New York, 622-636.

Toufexis, N. (2008), “Diglossia and Register Variation in Medieval Greek”, in: Byzantine and Modern Greek Studies 32, 203-217.

Trapp, E. (1993), “Learned and Vernacular Literature in Byzantium: Dichotomy or Symbiosis?", in: Dumbarton Oaks Papers 47, 115-129.

Trapp, E. et al. (eds.) (1988), Studien zur byzantinischen Lexikographie, Wien.

Trapp, E./Schönauer, S. (eds.) (2007), Lexicologica Byzantina: Beiträge zum Kolloquium zur byzantinischen Lexikographie (Bonn, 13.-15. Juli 2007), Bonn.

Tribulato, O. (2014), “'Not even Menander Would Use this Word!': Perceptions of Menander's Language in Greek Lexicography”, in: A. Sommerstein (ed.), Menander in Contexts, New York/London, 199-214.

Tribulato, 0. (2016), “Herodotus' Reception in Ancient Greek Lexicography and Grammar: From the Hellenistic to the Imperial Age”, in: J. Priestley/V. Zali (eds.), Brill's Companion to the Reception of Herodotus in Antiquity and Beyond, Leiden/Boston, 169-192.

Tribulato, 0. (2018), “Le epistole prefatorie dell'Onomasticon di Polluce: frammenti di un discorso autoriale", in: Lexis 36, 247-283.

Ucciardello, G. (2006), "Esegesi linguistica, glosse ed interpretamenta tra hypomnemata e lessici: Materiali e spunti di riflessione”, in: G. Avezzù/P. Scattolin (eds.), I classici greci e $i$ loro commentator: Dai papiri ai marginalia rinascimentali. Atti del convegno, Rovereto 20 ottobre 2006, Rovereto, 35-83.

Ucciardello, G. (2009), “Hyperides in the Archimedes Palimpsest: Palaeography and Textual Transmission", in: BICS 52, 229-252.

Ucciardello, G. (2012a), "Iperide tra età tardoantica e medioevo: I percorsi del testo nella tradizione retorica”, in: F.G. Hérnandez Muñoz (ed.), La tradición y la transmisión de los oradores y rétores griegos - Tradition and Transmission of Greek Orators and Rhetors, Berlin, 303-330.

Ucciardello, G. (2012b), Hypomnemata papiracei e lessicografia: Tra Alessandria e Bizanzio, Messina.

Valente, S. (2008), “Una miscellanea lessicografica del X secolo: Il Par. Coisl. 345”, in: Segno e testo $6,151-178$.

Valente, S. (2012), I lessici a Platone di Timeo Sofista e Pseudo-Didimo: Introduzione ed edizione critica, Berlin/Boston. 
Valente, S. (2015), The Antiatticist: Introduction and Critical Edition, Berlin/Boston.

van den Gheyn, J. (1899), “Acta Graeca SS. Davidis, Symeonis et Georgii, Mitylenae in insula Lesbo", in: Analecta Bollandiana 18, 209-259.

Vessella, C. (2010), "Reconstructing Phonologies of Dead Languages: The Case of Late Greek $<\eta\rangle$, in: Rivista di Studi Orientali 84, 257-271.

Vessella, C. (2018), Sophisticated Speakers: Atticistic Pronunciation in the Atticist Lexica, Berlin/Boston.

Wirth, P. (1966), “Wohin ward Nikephoros Basilakes verbannt?”, in: ByzForsch 1, 289-392.

Wolska-Conus, W. (1968), Cosmas Indicopleustès: Topographie Chrétienne, vol. 1: Livres I-IV, Paris.

Wolska-Conus, W. (1970), Cosmas Indicopleustès: Topographie Chrétienne, vol. 2: Livre V, Paris. 